\title{
The Litigation Process in Handling Murabahah Cases: A Comparative Study between Malaysia and Indonesia
}

\author{
Atharyanshah Puneri, \\ Ilhamiddin Ikramovich Nazarov, \\ Moustapha Chora Ahmat, and \\ Muhamad Ikhwan Arif
}

\section{International Islamic University Malaysia (IIUM)}

\begin{abstract}
In conventional banking, the validity of a contract is recognised through case law and the legal system of the country. Islamic banking contracts follow the same laws in addition to Shariah principles, which sometimes create legal uncertainty. Murabahah is an Islamic financial instrument which allows a buyer to purchase goods from a seller at a specified profit margin. In contemporary banking practice, Murabahah has been widely used by Islamic financial institutions as a financing contract. It is therefore important to scrutinise the legality and validity of Murabahah practised by Islamic financial institutions in contemporary settings because the existing substantive law on contracts and commerce may not fit well with the Shariah principles. This paper selected three Murabahah cases in Malaysia and Indonesia between 2013 and 2016 as points of comparison. Future research could compare and contrast legal cases over a wider time span.
\end{abstract}

Keywords: Murabahah; Civil Court; Religious Court; Malaysia; Indonesia; Legal System; Islamic Banking Dispute 


\section{Introduction}

Modern Islamic banking and finance is an emerging industry across the globe. In Malaysia the total assets of the Islamic banking industry reached USD190 billion in 2018 whereas the Islamic banking industry in Indonesia reached USD30 billion in 2018 (Islamic Financial Services Board, 2019). One of the main things that affect the growth of the Islamic finance industry is the regulatory framework in many different countries. While the nature of the legal system of Islam is different from the governing law, Islamic banks are subject to the same legal system as mainstream commercial banks. It is therefore important for regulatory authorities to ensure that neither mainstream banks nor Islamic financial institutions are disadvantaged.

Conventional courts typically do not understand the legal implications of Shariah financial transactions. In cases where the courts are tasked with resolving commercial disputes in accordance with Islamic law, courts are thrust into a complex task to achieve the delicate balance between religious and secular law. Hence, this paper aims to examine court decisions relating to Islamic banking in Malaysia and Indonesia.

Murabahah (cost-plus mark up) is a contract between the customer and the bank that authorises the bank to purchase the goods and sell them back to the customer in deferred instalments without loan interest. The customer then pays the financier on a deferred sale basis with a return that reflects the profit of the establishment (Bank Negara Malaysia, 2013). Islamic banks retain the ownership of the sold commodity as a pledge until the outstanding balance is cleared (Ali and Zada, 2019; Ismal, 2013; Saadallah, 2007). The Murabahah contract is frequently used by Islamic banks in Malaysia and Indonesia for financing the sale and purchase of machinery, commodities and equipment. The execution of Murabahah becomes complicated in modern days because Islamic injunctions require a seller to own the asset prior to entering a sale contract. Islamic financial institutions, like conventional mainstream financial institutions, are not in the business of holding and reselling goods. Common Islamic banking practices include combining Murabahah with other Islamic financial instruments such as Wakalah (Ayub, 2009) and Tawarruq (Ahmad et al., 2017).

This paper seeks to analyse the judicial system in two jurisdictions -- Indonesia and Malaysia -- within the context of Islamic finance disputes, with a special focus on the courts' decisions on Murabahah cases. The researchers in this study selected Malaysia and Indonesia since these two neighbouring countries are among the earliest pioneers in Islamic banking and finance in the region. In Malaysia, Islamic law is only applicable to Muslims and application is limited to matrimonial issues, property matters and religious offences. In addition, Shariah Courts only have jurisdiction with regards to matters falling under the State list in the Federal Constitution. The civil court is the forum to hear and decide on banking matters for both conventional and Islamic financial institutions. By contrast, Islamic banking legal cases in Indonesia fall under the authority of the Religious Courts. Law No. 3 of 2006 the amendment of Law No. 7 of 1989 renewed by Law No. 50 of 2009 brought significant changes in the authority of Religious Courts at the time of writing. Under said Law, dispute resolution through litigation is under the purview of the Religious Courts.

International Journal of Management and Applied Research, 2019, Vol. 6, No. 4 


\section{Islamic Banking Regulation and use of Murabahah in Malaysia}

In Malaysia, Islamic financial institutions offer various Islamic financing products. The Murabahah contract is one of the most widely used contracts for personal financing and capital markets. According to Bank Negara Malaysia (2019), Murabahah contracts make up nearly half of the total financing offered by Islamic banks, approximately 208 million Ringgit Malaysia out of 512 million Ringgit Malaysia total financing.

The Financial Services Act 2013 is the key statute governing the finance industry while Islamic financial institutions are governed by the Islamic Financial Services Act 2013. The Shariah Advisory Council (SAC) of Bank Negara Malaysia has the statutory authority to issue rulings on Shariah matters under a reference made to it under the Central Bank of Malaysia Act 2009. A court can refer to SAC on any question concerning matters related to Islamic financial businesses. The ruling of SAC is binding on the court (sections 56 and 57, Central Bank of Malaysia Act 2009). In the event of conflict between SAC and a Shariah committee constituted in Malaysia by an Islamic financial institution, the rulings of the $\mathrm{SAC}$ in Islamic financial matters prevail (section 58, Central Bank of Malaysia Act 2009).

The Federal Constitution is the main statute that regulates the jurisdiction of the courts in Malaysia. Islamic banking matters falls under the Civil Court since Islamic banking matters come under the realm of "mercantile law" which falls under Civil Court authority (items 7 and 8, under Federal List of Constitution of Malaysia 1957). Although the rulings of SAC are binding on Civil Courts, the Civil Courts apply Malaysian and English laws in settling Islamic banking cases.

\section{Islamic Banking Regulation and use of Murabahah in Indonesia}

In 2000, Dewan Syariah Nasional (National Shariah Board) issued a ruling about Murabahah in their Fatwa No: 04/DSN-MUI/IV/2000. Since the introduction of Law No. 3 of 2006 and the Sharia Banking Act in 2008, there is an increasing number of Islamic financial institutions operating in the country (Juwana et al., 2008) and Murabahah has become the most commonly used contract for financing in Islamic Banking in Indonesia. According to the Sharia Banking Statistics from Otoritas Jasa Keuangan (2019), Murabahah financing comprises over half of all financing by Islamic banks in Indonesia, with over 150 Billion Rupiah worth of receivables since 2017.

Religious Courts in Indonesia are given authority to mediate and resolve cases related to Islamic banking, as indicated in Law No.21 of 2008 on Sharia Banking as well as Law No. 3 of 2006. In addition to Islamic finance, Religious Courts have jurisdiction over family (civil) matters such as marriage and inheritance as well as waqf (Islamic endowment). Before the Islamic Banking Law came into effect in 2008, the judges of the Religious Courts dealt almost exclusively with family law and they have shown limited efforts in exploring the highly challenging and complex area of Islamic finance (Lindsey, 2012). Religious Courts are given guidance related to Islamic banking, Kompilasi Hukum Ekonomi Syariah (Compilation of Syariah Economic Law) which

International Journal of Management and Applied Research, 2019, Vol. 6, No. 4 
consists of 796 articles, most of which are drawn from fatwa published by the Dewan Syariah Nasional (National Shariah Board) and a selection of fiqh (classical legal literature) on Islamic finance (Lindsey, 2012). Cammack and Feener (2012) noted that the civil court judges lack necessary training in Islamic banking and finance.

\section{Analysis of Murabahah Cases in Malaysia}

The study collected legal documents, legal treatises and relevant scholarly works for document analysis (Bowen, 2009). Not all legal cases have been included in this study. The inclusion criteria for document analysis in this study are: firstly, court cases dealing with Murabahah transactions; secondly, legal disputes that occurred between 2013 and 2016. Table 1 summarises selected Murabahah cases in Malaysia.

Table 1: Selected Cases of Murabahah in Malaysia

\begin{tabular}{lc}
\hline Cases & Date of Decision \\
\hline CIVIL SUIT NO D-22A-517 OF 2010 & 7 Jan 2013 \\
Bank Islam Malaysia Bhd v Sunwai Trading Sdn Bhd \& Ors & \\
[2013] 9 MLJ 692 & 5 Feb 2014 \\
CIVIL SUIT NO 22M-88-08 OF 2013 & \\
Bank Muamalat Bhd v Hexagon Holdings Bhd [2015] 7 MLJ 134 & 17 May 2016 \\
CIVIL APPEAL NO: W-02(MUA)(W)-1595-09/2014 & \\
Islamic Berhad v M-IO Builders Sdn Bhd \& Anor & \\
\hline
\end{tabular}

\subsection{Bank Islam Malaysia Bhd v Sunwai Trading Sdn Bhd \& Ors}

The first defendant had been granted three Islamic banking facilities; one of them was Murabahah Working Capital for the purpose of funding its import and export businesses. When the first defendant failed to make instalment payments on time, the plaintiff issued a notice of default dated 28 January 2010 to suspend the first defendant's banking facilities. The plaintiff was granted summary judgement against the defendants in respect of the notice and default. However, in the counterclaim, the first defendant had contended that the plaintiff had wrongfully frozen the first defendant's banking facilities based on an email dated 15 January 2010, which had been sent to a number of employees who work for the plaintiff. The first defendant argued that the plaintiff had wrongfully frozen its account and that the defendant was unable to proceed with the contracts it had entered into with suppliers. In response to that, the plaintiff claimed that the first defendant's account was frozen due to some suspicious invoices submitted to the bank (plaintiff). However, the plaintiff was unable to provide supporting evidence to back up such claim.

The court held that:

1. Based on the available evidence, it was clear that the first defendant's account was frozen on $15^{\text {th }}$ January 2010 due to the circulated email dated $15^{\text {th }}$ January 2010.

2. Due to the absence of evidence supporting the plaintiff's claim of suspicious invoices, since there was no evidence put forth by the plaintiff relating to the claim of suspicious invoices, which resulted in the decision to freeze the first defendant's account

International Journal of Management and Applied Research, 2019, Vol. 6, No. 4 
3. The first defendant was entitled to an award of nominal damages at RM 5,000 for want of proof.

No further appeal was recorded for this case in the court, after the judgment was made.

\subsection{Bank Muamalat (M) Bhd v Hexagon Holdings Bhd}

The plaintiff had granted financing facilities to two companies: Metal Advance Substrate Technology Sdn Bhd and Hexagon Tower Sdn Bhd (defendant). The facilities were provided based on tawarruq (reverse Murabahah). The payments of the facilities were guaranteed by the defendant executing a corporate guarantee and indemnity agreement and a deed of guarantee and indemnity. Both companies defaulted repayment. The plaintiff was pursuing against the defendant as the corporate guarantor. The plaintiff exhibited a certificate of indebtedness which indicated the outstanding balance and the plaintiff applied to enter summary judgment against the defendant.

The defendant raised the following tri-able issues: first, the certificate of indebtedness was not conclusive because it did not mention the name of the plaintiff and the defendant; second, the certificate did not clearly depict the breakdown of the amount due; third, the defendant did not receive any consideration from the corporate guarantees and indemnities.

After hearing evidence, the judge found that the plaintiff had exhibited sufficient documents as required by the law. On the other side, the defendant's affidavit contained denials and did not constitute evidence. The judge allowed the application of the plaintiff with cost of RM 4,000. No reference to Shariah Advisory Council is recorded.

\subsection{Maybank Islamic Berhadv M-IO Builders Sdn Bhd \& Anor}

Maybank Islamic Bhd v M-IO Builders Sdn Bhd \& Anor [2017] 2 MLJ 69 - CA is an appeal case. The appellant granted Murabahah financing facilities to the first respondent and the second respondent was the guarantor, under a letter of offer dated 31 July 2003. The bank restructured the financing facility and issued a second letter of offer dated 8 December 2004. The appellant bank contended that the second letter of offer superseded the first letter of offer whereas the first respondent insisted otherwise. The High Court held that the revised letter of offer breached the Murabahah Concept of Financing (Maybank Islamic Bhd v M-IO Builders Sdn Bhd \& Anor [2015] 4 CLJ 526 HC). The bank appealed in 2016.

After hearing evidence, the judges concluded that the evidence submitted by the plaintiff had not been rebutted according to law sufficiently proving a prima facie case against the defendants both on liability and quantum. The Court of Appeal allowed the appeal and dismissed the cross-appeal with costs of RM100,000 to the appellant and ordered that the deposit be refunded. With regard to the claim for damages, the learned judge found the RM2 million claim unsubstantiated. No reference to the Shariah Advisory Council is recorded.

International Journal of Management and Applied Research, 2019, Vol. 6, No. 4 


\section{Analysis of Murabahah Cases in Indonesia}

For the purpose of this study, three Murabahah cases in Indonesia occurring between 2013 and 2016 were chosen. Table 2 summarises the selected Murabahah cases in Indonesia.

Table 2: Selected Murabahah Cases in Indonesia

\begin{tabular}{lc}
\hline Cases & Date of Decision \\
\hline 0945/Pdt.G/2014/PA.ME: & 26 Feb 2015 \\
BNI Syariah Kantor Cabang Prabumulih v Petani Karet & \\
1720/Pdt.G/2013/PA.Pbg: & 23 Sept 2013 \\
BPRS Buana Mitra Perwira v Mulia Lastro Wibowo & 7 Apr 2015 \\
0488/Pdt.G/2014/PA.CN: & \\
Noor Karoline v Bank Victoria Syariah & \\
\hline
\end{tabular}

\subsection{BNI Syariah Kantor Cabang Prabumulih v Petani Karet}

On 22 December 2014, BNI Syariah Bank as the plaintiff sued the defendant in the Religious Court in Muara Enim for breach of Murabahah Contract. On $28^{\text {th }}$ June 2013, the plaintiff gave a Murabahah financing facility to the defendant to buy a rubber estate with the value of $\mathrm{Rp} 45,000,000$. Based on the Murabahah contract, the defendant had to pay monthly instalment of Rp 2,015,000 per month for 36 months to the plaintiff. The defendant paid his instalments on time for six consecutive months but stopped paying instalments at the seventh month. Since the defendant put up the rubber estate that he bought as the collateral for the Murabahah contract the plaintiff asked the judge in the court for security seizure of that land. The defendant did not show up in court.

In this case, the judge concluded that:

1. Granting Plaintiff's claim as admissible (verstek).

2. Plaintiff can put the security seizure for the collateral (the rubber estate).

3. Defendant was in breach of the Murabahah contract (contract number 00129/866/04/2013/06).

4. Defendant must pay the remaining amount to the plaintiff to the value of $\mathrm{Rp}$ $60,450,000$.

5. Defendant also must pay Rp 3,216,000 as court costs.

The judge in this case reviewed the Murabahah by looking at the Quran verse and also Indonesian law in reviewing whether the Murabahah contract being used here was Shariah compliant and legally compliant or not. The judges concluded that the Murabahah Contract in this case is both Shariah and legally complaint.

\subsection{BPRS Buana Mitra Perwira v Mulia Lastro Wibowo}

The plaintiff in this case, Bank Pembiayaan Rakyat Syariah (BPRS) Buana Mitra Perwira sued Mulia Lastro Wibowo for breach of Murabahah Contract Number 43, dated 18 August 2010. A Murabahah financing facility was given to defendant to purchase a car. The plaintiff sued the defendant due to them being unable to pay instalments as promised. The defendant did not show up in court and the judges only looked at the contracts and the facts explained in the court. No reference to Shariah principle was recorded.

International Journal of Management and Applied Research, 2019, Vol. 6, No. 4 
In this case, the judge concluded that:

1. Granting the plaintiff's claim as admissible (verstek)

2. The defendant was in breach of the Murabahah Contract No. 43

3. The defendant must pay the actual loss that the plaintiff sustained valued at Rp $59,826,602$.

4. The defendant also must pay Rp 641,000 as court costs.

\subsection{Noor Karoline v Bank Victoria Syariah}

Noor Karoline, the plaintiff submitted an application for venture capital to Bank Victoria Syariah (defendant) and both parties entered into a Wakalah Agreement under Murabahah financing. Under this agreement, the plaintiff was given the right to buy goods at a purchase price of $\mathrm{Rp} \mathrm{101,000,000} \mathrm{to} \mathrm{fund} \mathrm{her} \mathrm{business.} \mathrm{The} \mathrm{plaintiff} \mathrm{had}$ made instalment payments totalling $\mathrm{Rp} 72,284,918$. However, she was having difficulty in repaying the outstanding balance because her business was underperforming. The defendant in this case, Bank Victoria Syariah foreclosed on the property of the plaintiff which had been put up as collateral. The plaintiff claimed that Bank Victoria Syariah violated the Shariah principles of Murabahah and Wakalah. Under the Wakalah agreement and Murabahah financing contract, the defendant in this case retains the right to the purchased goods (Ali and Zada, 2019; Ismal, 2013; Saadallah, 2007) not the property owned by the plaintiff. The plaintiff also claimed that the defendant intimidated her for instalment payments during praying hours, causing her emotional distress. The defendant denied all claims made by the plaintiff and they argued that they acted according to the law and contractual agreement in the event of default.

The Court held that:

1. The plaintiff's claim was inadmissible (Niet Ontvankelijke Verklaard).

2. The plaintiff to pay court fees of $\operatorname{Rp} 3,781,000$

\section{Discussion and Findings}

Based on the above six cases, there are several similarities and differences that can be observed relating to court decision on Murabahah cases and Islamic Banking in general. Firstly, the judges rely on the procedural issues and substance of the contracts concluded between the parties. It can be seen in the case of Maybank Islamic Berhad $v$ $M-I O$ Builders Sdn Bhd \& Anor where the judges in High Court held that the contract of Murabahah was inconsistent with Shariah principles but the Court of Appeal allowed the appeal. No reference to the Shariah Advisory Council is recorded in the appeal. Hence, it appears that the judges in Court of Appeal upheld the sanctity of a valid contract as the contracting parties have complied with the procedural requirement, without looking fundamental principles behind the agreements and considering the substantive law and Shariah principles.

Secondly, both courts in Malaysia and Indonesia give legal recognition to Shariah permissibility in judgments in Islamic financial cases. By law, the ruling of authoritative body (Shariah Advisory Council) is binding on the court in Malaysia. The judges in Indonesia's Religious Courts, on the other hand, are given a detailed

International Journal of Management and Applied Research, 2019, Vol. 6, No. 4 
selection of fiqh and fatwa related to Islamic finance (Lindsey, 2012) and they are expected to master knowledge of Islamic finance in addition to family law. However, the judges in both countries may not fully aware of the complexities of Islamic finance and they appeared to be in favour of common law and civil law over of Shariah law.

Furthermore, both Malaysian and Indonesian judges applied a justice and equity approach in making court decisions. Judges have the power to set aside a contract which is grossly unfair to one of the contracting parties (Markom et al., 2013). There is a case in Malaysia which is Bank Islam Malaysia Bhd v Sunwai Trading Sdn Bhd \& Ors, where the court decided to allow the defendant's counterclaim after reading through all evidence from both parties. The defendant failed to present supporting evidence against the plaintiff. Similarly, in Indonesia, the defendants in the cases of BNI Syariah Kantor Cabang Prabumulih v Petani Karet and BPRS Buana Mitra Perwira v Mulia Lastro Wibowo did not show up in court. Due to the absence of the defendants, the judgements are in favour of the plaintiffs of these two cases and the judges did not discuss the Shariah principles governing the Islamic Banking facilities. Although it is the duty of the court to seek expert opinion on Shariah matters, the judge has the power to decide whether it is necessary to do so. In these three cases, the question before the court was the application of the terms of the contractual documents and not a question of Shariah law. The issue of the validity of Islamic facilities was neither raised nor argued by the counsels acting for the parties (Markom et al., 2013).

The main difference between Malaysian and Indonesian judges is that, it is not compulsory for Malaysian judges to have knowledge of Islamic finance; they can consult with the Shariah Advisory Council in dealing with Islamic finance cases. Judges in Malaysia should not take it upon themselves to rule that Murabahah cases or any other Islamic financial instruments that are contrary to Shariah principles, without having regard to the ruling of the Shariah Advisory Council of the Central Bank and the Shariah Advisory Body of the bank (Markom et al., 2013). In contrast, Indonesian judges in Religious Courts are required to have a law degree from an Islamic institute (Cammack and Feener, 2012) and are expected to understand Islamic finance (Lindsey, 2012).

Another main difference between these two countries is the legal system; while the law of Malaysia is mainly based on the common law legal system, the law of Indonesia is based on a civil law system, intermixed with customary law and Roman Dutch law. In Malaysia, the judges are bound to follow the judgements of previous cases according to procedural law. Meanwhile in Indonesia, previous cases become references for the judges and they cannot use previous cases as a benchmark.

\section{Conclusion}

Islamic banking cases have received increasing attention with the growth of Islamic finance in recent years. However, the rising number of Islamic banking cases arises from the lack of conformity between Sharia law and governing law. The current banking law and regulations in most jurisdictions forbid commercial banks to undertake activities like Murabahah (Ahmed and Khan, 2007, p. 146).

International Journal of Management and Applied Research, 2019, Vol. 6, No. 4 
This study examined Murabahah cases in Malaysia and Indonesia and found at least three similarities and two differences. The similarities are as follows: first, the judges place more emphasis on procedure than substance; second, in cases where Islamic principle is incompatible with national law, the governing law always prevails; and lastly, the judges adopt a justice and equity approach in making judicial decisions. In terms of differences between the two countries, both countries differ in their legal system and qualification requirements for judges. Malaysian judges are bound to follow decisions made by judges in earlier cases under common law, whereas Indonesian judges are not bound to follow previous cases but to use them as reference. In Malaysia, Islamic banking cases are under the jurisdiction of the Civil Court and Islamic banking cases in Indonesia are under the jurisdiction of the Religious Court. Additionally, all Islamic court judges in Indonesia are required to have a law degree from an Islamic institute (Cammack and Feener, 2012).

Given the dynamism of the Islamic finance industry, bridging the gap between Islamic financial theory and practice - and religious and secular commercial law - often gives rise to uncertainty. Further legislative measures and changes are needed to accommodate Islamic financing practice in the legal systems of Malaysia and Indonesia to make it a truly viable alternative system of financing for Muslims in these countries.

\section{References}

1. Ahmad, E. F.; Shihama, M.; Mohamad Tarmizi, N. A.; Jibril, S. M.; Djama, S. I. and Muneeza, A. (2017), "Tawarruq as a Product for Financing within the Islamic Banking System: A Case Study of Malaysian Islamic Banking System", International Journal of Management and Applied Research, Vol. 4, No. 1, pp. 3143.https://doi.org/10.18646/2056.41.17-004

2. Ahmed, H. and Khan, T. (2007), "Risk management in Islamic banking", in: Hassan, M. K. and Lewis, M. K. (Ed), Handbook of Islamic Banking, Cheltenham: Edward Elgar Publishing Limited, pp. 144-160.

3. Ali, M. and Zada, N. (2019), The Islamic Finance Trading Framework: Legitimizing Profit Making, Switzerland: Springer.

4. Ayub, M. (2009), Understanding Islamic Finance, UK: John Wiley \& Sons.

5. Bank Negara Malaysia (2013), Murabaha [Online] available from: http://www.bnm.gov.my/guidelines/05_shariah/CP_Murabahah_122013.pdf [accessed on 18 October 2019].

6. Bank Negara Malaysia. (2019), 1.18.2 Islamic Banking System: Financing by Concept, [Online] available from: http://www.bnm.gov.my/index.php?ch=en_publication\&pg=en_msb\&ac=266\&lan $\mathrm{g}=\mathrm{en} \& \mathrm{uc}=2$ [accessed on 18 October 2019].

International Journal of Management and Applied Research, 2019, Vol. 6, No. 4 
7. Bowen, G. (2009), "Document Analysis as a Qualitative Research Method", Qualitative Research Journal, Vol. 9 No. 2, pp. 27-40.

https://doi.org/10.3316/QRJ0902027

8. Cammack, M. E. and Feener, R. M. (2012), "The Islamic Legal System in Indonesia”, Pacific Rim Law \& Policy Journal, Vol. 21, No. 1, pp. 13-42

9. Central Bank of Malaysia Act 2009

10. Constitution of Malaysia 1957

11. Ismal, R. (2013), Islamic Banking in Indonesia: New Perspectives on Monetary and Financial Issues, Singapore: John Wiley \& Sons.

12. Juwana, H.; Barlinti, Y. And Dewi, Y. (2008), "Shaira law as system of governance in Indonesia: The development of Islamic financial law", Wisconsin International Law Journal, Vol. 25, No. 4, pp. 773-796.

13. Law No.21 of 2008 on Sharia Banking (Undang-Undang Republik Indonesia Nomor 21, Tahun 2008, tentang Perbankan Syariah)

14. Law No. 3 of 2006 on Religious Courts (Undang-Undang Republik Indonesia Nomor 3, Tahun 2006, tentang Peradilan Agama)

15. Lindsey, T. (2012), "Between piety and prudence: State Syariah and the regulation of Islamic banking in Indonesia", Sydney Law Review, Vol. 34, pp. 107-127.

16. Markom, R.; Pitchay, S. A.; Zainol, Z. A.; Rahim, A. A.; Merican, R.; Rahim, A. and Merican, R. (2013), "Adjudication of Islamic banking and finance cases in the civil courts of Malaysia”, European Journal of Law and Economics, Vol. 36, No. 1, pp. 1-34. https://doi.org/10.1007/s10657-011-9249-4

17. Otoritas Jasa Keuangan (OJK) (2019), Shariah Banking Statistics: July 2019. Jakarta: OJK, [Online] Available from: https://ojk.go.id/en/kanal/perbankan/datadan-statistik/statistik-perbankan-syariah/Documents/Pages/Sharia-BankingStatistic---July-2019/Sharia\%20Banking\%20Statistic\%20July\%202019.pdf [Accessed on 18 October 19].

18. Saadallah, R. (2007), "Trade Financing in Islam”, in: Hassan, M. K. and Lewis, M. K. (Eds), Handbook of Islamic Banking, Cheltenham: Edward Elgar Publishing, pp. 172-190.

International Journal of Management and Applied Research, 2019, Vol. 6, No. 4 